\title{
Orchid bees: a new assessment on the rarity of diploid males in populations of this group of Neotropical pollinators
}

\author{
Douglas C. Giangarelli1 ${ }^{1,2}$, Gabriele A. Freiria ${ }^{1,3}$, Dhiego G. Ferreira ${ }^{1,3}$, \\ Willian M. Aguiar ${ }^{4,5}$, Rafael E.S. PenhA ${ }^{1,3}$, Alessandra N. Alves ${ }^{1,3}$, \\ Maria C. Gaglianone ${ }^{4}$, Silvia H. Sofia ${ }^{1}$

\begin{abstract}
${ }^{1}$ Laboratório de Genética e Ecologia Animal, Departamento de Biologia Geral, CCB, Universidade Estadual de Londrina (UEL), Rod. Celso Garcia Cid, km 380, CP 10.011, 86057-990, Londrina, PR, Brazil

${ }^{2}$ Programa de Pós-Graduação em Ciências Biológicas, UEL, Londrina, Brazil

${ }^{3}$ Programa de Pós-Graduação em Genética e Biologia Molecular, UEL, Londrina, Brazil

${ }^{4}$ Laboratório de Ciências Ambientais, Programa de Pós-Graduação em Ecologia e Recursos Naturais, Universidade Estadual do Norte Fluminense Darcy Ribeiro, Av. Alberto Lamego, 2000, Parque Califórnia, 28013-602, Campos dos Goytacazes, RJ, Brazil

${ }^{5}$ Universidade Estadual de Feira de Santana, Av. Transnordestina, s/n, Novo Horizonte, 44036-900, Feira de Santana, BA, Brazil
\end{abstract}

Received 18 March 2014 - Revised 12 November 2014 - Accepted 20 January 2015

\begin{abstract}
The incidence of diploid males among 1457 individuals of different populations of six euglossine bee species (Eufriesea violacea ,Eulaema cingulata, Euglossa annectans, Euglossa iopoecila, Euglossa pleosticta and Euglossa truncata) was investigated with microsatellite markers. Bees were surveyed in Atlantic Forest fragments showing different sizes and degrees of human interference. Our analyses revealed that, although the frequencies of diploid males remained below $10 \%$ for five out of six species studied, the frequencies of these males in three populations of Eg. annectans were above $15.0 \%$. For this species, while the average estimate of diploid males was around $11.0 \%$, the highest percentage $(27 \%)$ of such males was found for the population from an island. Our findings indicate that the frequency of diploid males can vary substantially among species and this fact should be taking into consideration in studies and conservation actions involving different euglossine bees.
\end{abstract}

microsatellites / Euglossini / euglossine bees / Euglossa annectans / forest fragments

\section{INTRODUCTION}

Bees and other hymenopteran insects are characterized by haplodiploidy, with arrhenotokous parthenogenesis as the common mode of reproduction (Cook 1993; Harpur et al. 2013). Among these insects, sex is determined by ploidy, by

Electronic supplementary material The online version of this article (doi:10.1007/s13592-015-0350-5) contains supplementary material, which is available to authorized users.

Corresponding author: S. H. Sofia, shsofiabelh@gmail.com

Manuscript editor: Yves Le Conte which unfertilized eggs develop into haploid males and fertilized eggs usually develop into diploid females (Cook 1993; Cook and Crozier 1995; Harpur et al. 2013).

At genic level, the single locus complementary sex determination (sl-CSD), which depends on allelic variation at a sex locus, is one of several mechanisms of sex determination in hymenopterans. Considered widespread in bees, sl-CSD is present among social and non-social bees (van Wilgenburg et al. 2006; Zayed et al. 2004; Zayed 2009). Heterozygotes at the CSD locus develop into diploid females; however, when homozygous at this locus, instead of females, diploid males ( $2 \mathrm{~N}$ males) are produced from fertilized 
eggs (Unruh and Messing 1993; Zayed et al. 2004; van Wilgenburg et al. 2006). Although, several recent studies have shown that $2 \mathrm{~N}$ males are viable (Cowan and Stahlhut 2004; Elias et al. 2009; Harpur et al. 2013), they usually exhibit low fitness (Unruh and Messing 1993) and are thus considered very costly to populations of haplodiploid insects (Crozier 1977; Unruh and Messing 1993; Beye et al. 2003; Heimpel and de Boer 2008; Zayed 2009; Harpur et al. 2013). In addition, considering that for each diploid male produced a functional female ceases to be raised, diploid males inflict a significant cost on the reproductive success of their parents (Unruh and Messing 1993; Zayed and Packer 2005; Zayed 2009).

In bees, diploid males have been observed in four families and in at least 27 species of both solitary and social bees (Zayed 2009). In the last two decades, several studies have investigated the frequency of diploid males in Euglossini (Roubik et al. 1996; Zayed et al. 2004; López-Uribe et al. 2007; Souza et al. 2010), a Neotropical group of bees popularly known as orchid bees considered to be important pollinators throughout the tropical Americas (Dressler 1982; Roubik and Hanson 2004).

Roubik et al. (1996) reported high frequencies of these males in populations of some species of Euglossini (e.g. Euglossa imperialis Cockerell) in Panama. This finding was corroborated by a second study that showed high levels of diploid male production and low effective population sizes (Zayed et al. 2004). Both of these studies were based on allozyme analyses (Roubik et al. 1996; Zayed et al. 2004), as was a study carried out by Takahashi et al. (2001), which found very different results. More recently, Souza et al. (2010), using microsatellite markers, analysed 1010 euglossine males, belonging to 27 different species across the Neotropics, and also detected very low frequencies of $2 \mathrm{~N}$ males for all samples studied. Based on their findings, Souza et al. (2010) suggested that diploid males are rare in orchid bees. However, it should be noticed that about $50 \%$ of the species surveyed by Souza et al. (2010) were represented by a restricted number of individuals $(\mathrm{n}<20)$ in the samples analysed. Thus, further studies involving larger samples would be interesting to confirm whether diploid males are in fact rare among orchid bees and if this hypothesis can be generalized for the group.

Some euglossine species are apparently sensitive to environmental disturbances (Powell and Powell 1987; Tonhasca et al. 2002; Giangarelli et al. 2009; Nemésio 2013), such as forest fragmentation and reduction in fragment size (Powell and Powell 1987; Sofia and Suzuki 2004; Giangarelli et al. 2009). Apart from reductions in the abundance of orchid bees in forest fragments of reduced size, studies have shown that some species may have stronger dispersal limitations in fragmented landscapes, and the type of matrix may also affect the dispersal of some species of the group differently (Powell and Powell 1987; Milet-Pinheiro and Schlindwein 2005).

Considering that declines in bee populations could result in genetic diversity loss (Cook 1993; Zayed 2009) and that in euglossine bees, the slCSD system has been proposed as the sexdetermining mechanism for different species of this group of bees (Zayed et al. 2004; van Wilgenburg et al. 2006; Souza et al. 2010), it would be expected that in small populations of these bees, a higher frequency of $2 \mathrm{~N}$ males should occur (Zayed et al. 2004; Zayed 2009). Despite this, to date, information regarding diploid male frequency in forest fragment showing different sizes and/or different degrees of disturbance is still scarce in the literature. Aiming to provide some information concerning this issue, the current study investigated the frequency of diploid males in populations of six species of orchid bees in Atlantic Forest fragments with different sizes and levels of preservation.

\section{MATERIALS AND METHODS}

\subsection{Study areas}

The 29 study sites where euglossine bees were collected are distributed throughout five different Brazilian states (Figure 1) located in southern and south-eastern Brazil as follows: in the southern region [States of Rio Grande do Sul (RS), Santa Catarina (SC), and Paraná $(\mathrm{PR})]$; and in the south-eastern region [States of São Paulo (SP) and Rio de Janeiro (RJ)]. The study sites consisted of areas that have different types of vegetation 


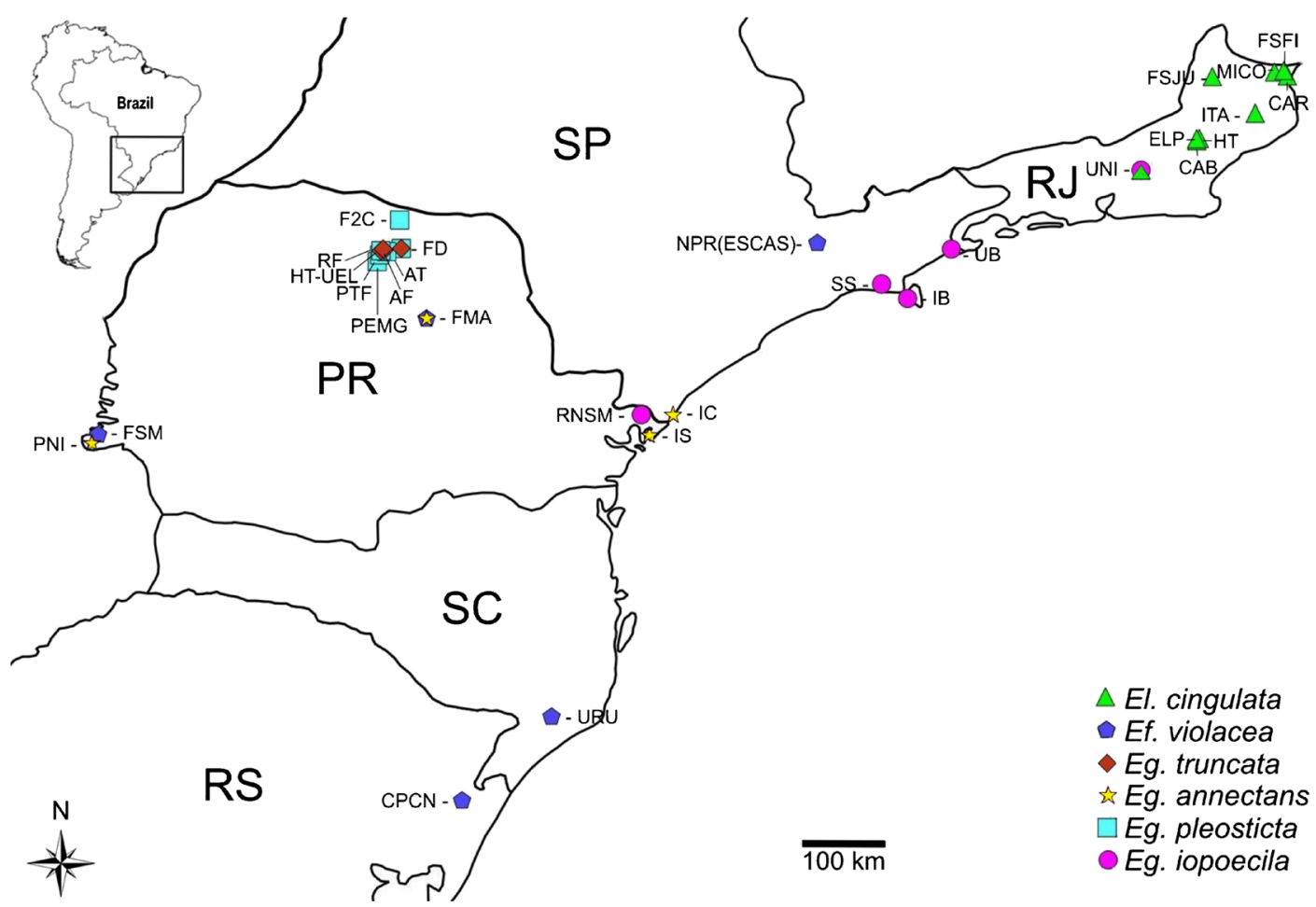

Figure 1. Map of Brazil, in South America, in detail, the 29 localities distributed in five Brazilian states (RS=Rio Grande do Sul, SC=Santa Catarina, PR=Paraná, SP=São Paulo and RJ=Rio de Janeiro) where males of the species Eufriesea violacea, Eulaema cingulata, Euglossa annectans, Euglossa pleosticta, Euglossa iopoecila and Euglossa truncata were sampled. Additional information on the 29 study sites, herein represented by codes (FSM, PEMG, FMA, ESCAS, CPCN, URU, CAB, UNI, ITA, FSJU, HT, MICO, CAR, ELP, FSFI, FD, F2C, PTF, AT, HT-UEL, RNSM, IS, PNI, IC, SS, IB, UB, AF and RF) are presented in Table I.

and degrees of preservation (Table I). Bees were sampled in remnants of dense forest (DF), seasonal semideciduous forest (SF) and Araucaria mixed forest (MF), which represent important types of Atlantic Forest ecosystems, located in private and governmental areas. Also, a few forest fragments located in urban areas, one of them representing a governmental park (AT), were surveyed for euglossine bees (Table I). The number of sites where bees were collected varied from four (Eg. truncata) to nine (El. cingulata).

While some study areas had very well preserved native vegetation characterized by large areas with primary forest, others were forest fragments with vegetation in different stages of regeneration (mainly ranging from intermediate to advanced successional stages), referred to as 'secondary forests'. Thus, in an attempt to characterize all of these areas, they were classified in one of three main categories of degree of disturbance: low, medium and high. For these three categories we took into consideration both the vegetation successional stage and the level of anthropogenic disturbance of the area.

\subsection{Bee sampling}

The analysis involved males of six species [Eufriesea violacea (Blanchard), Eulaema cingulata Fabricius, Euglossa annectans Dressler, Euglossa iopoecila Dressler, Euglossa pleosticta Dressler and Euglossa truncata Rebêlo and Moure] which are strongly associated with the Atlantic Forest (Nemésio and Silveira 2007; Nemésio 2009; Mattozo et al. 2011). Hereafter in the text the following abbreviations are used for different genera and commonly employed in studies on Euglossini: Ef. $=$ Eufriesea $;$ Eulaema $=E l$. and Eg. = Euglossa . 


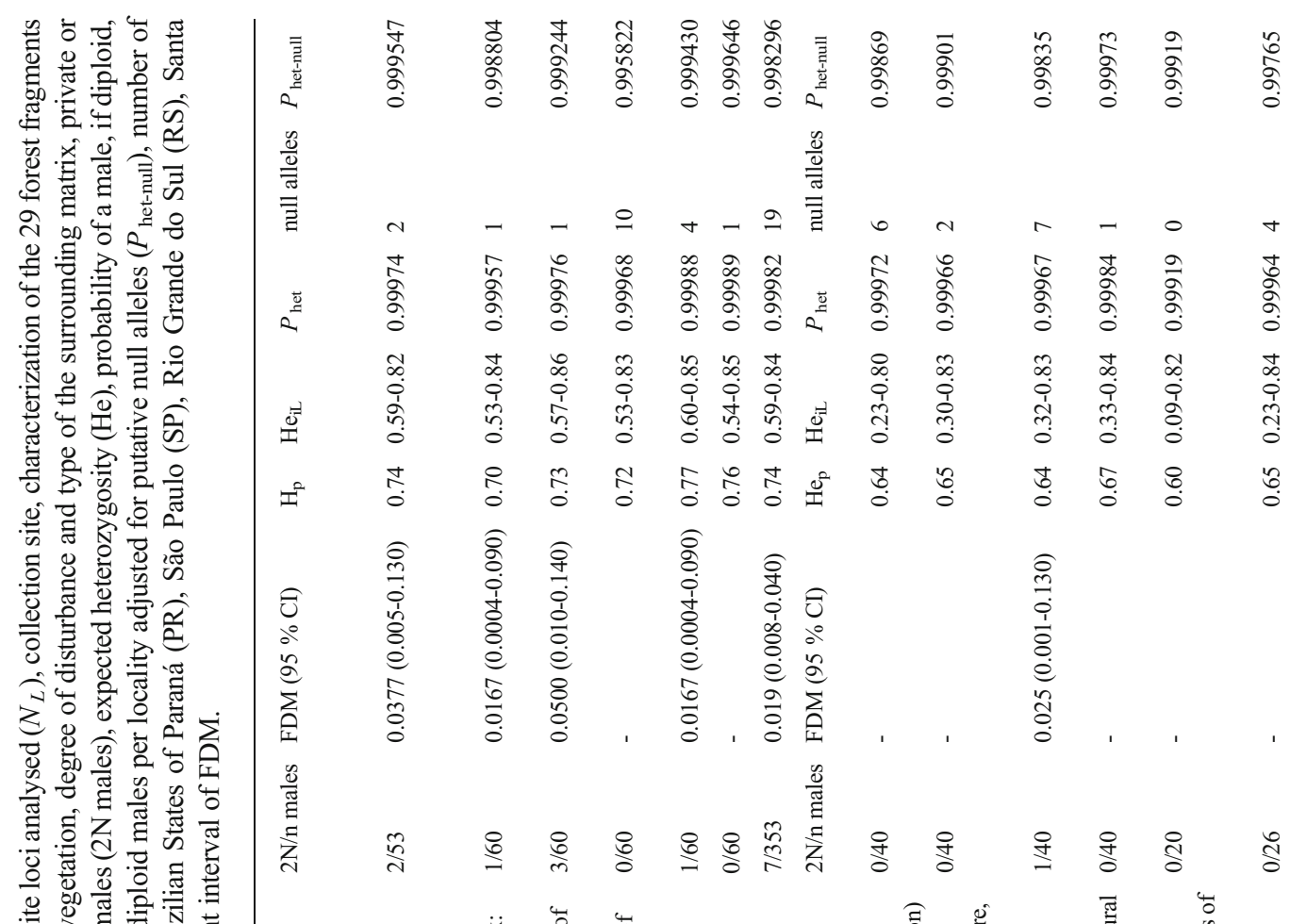

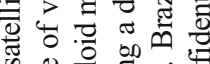

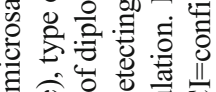

¿ 율

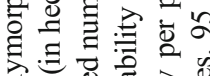

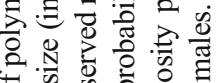

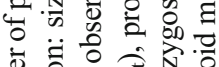

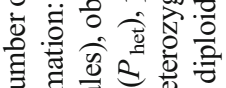

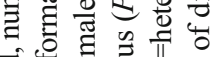

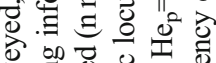
¿े.

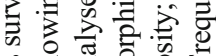

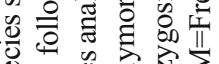

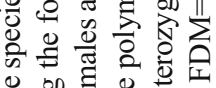

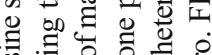
要至 की 龸

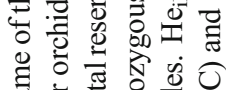

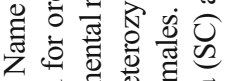

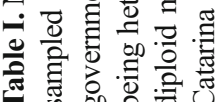

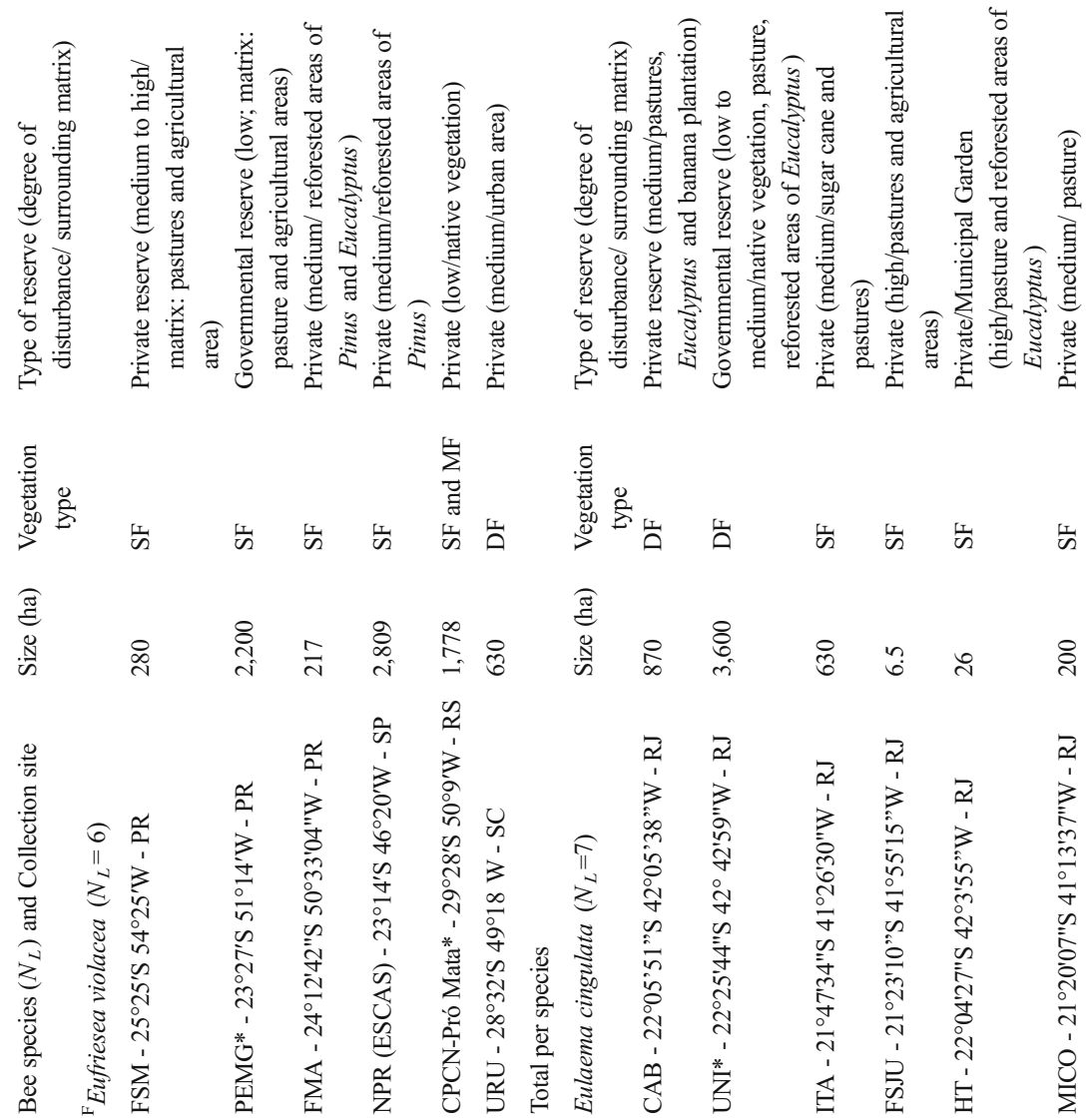




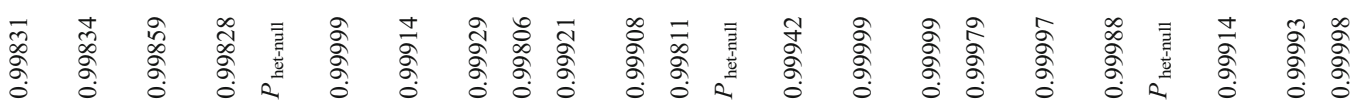

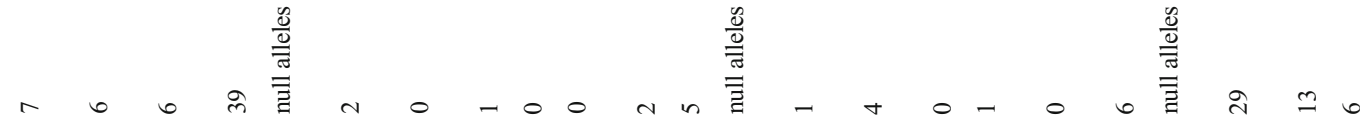

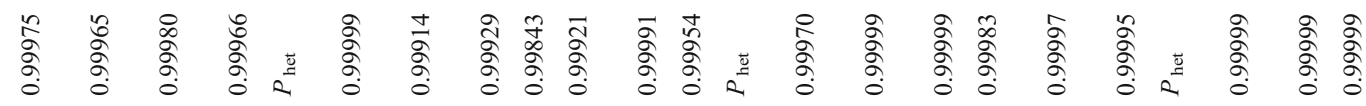

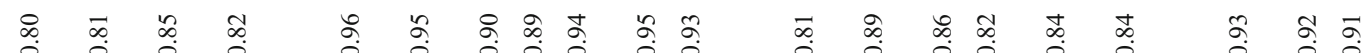

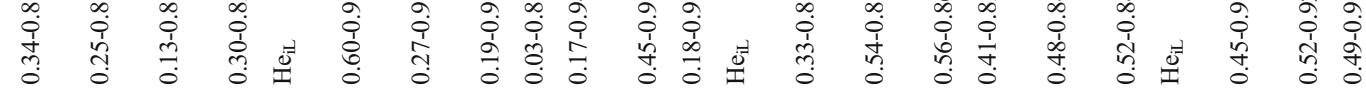

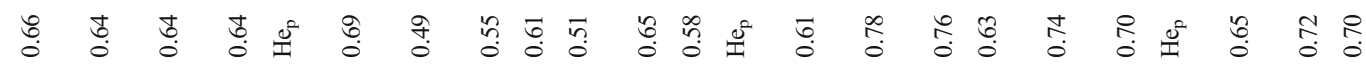

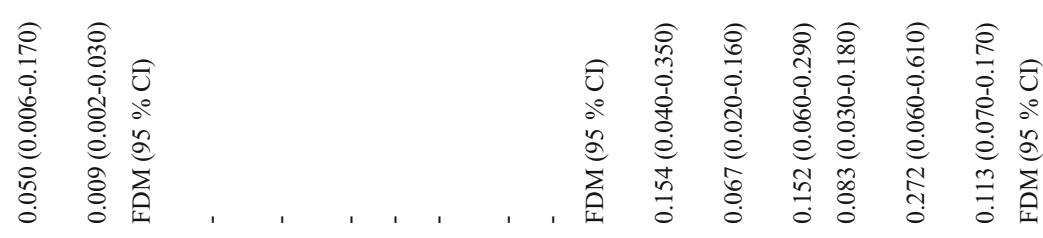

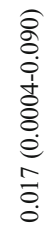

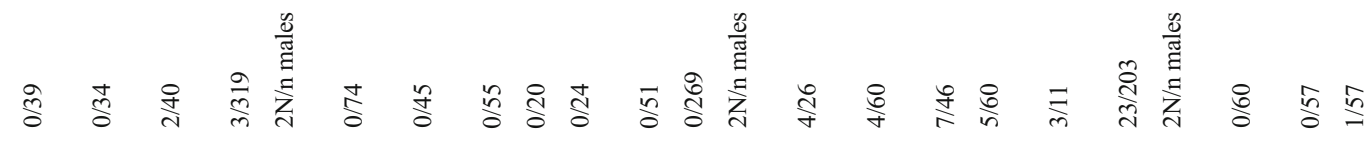
Sin

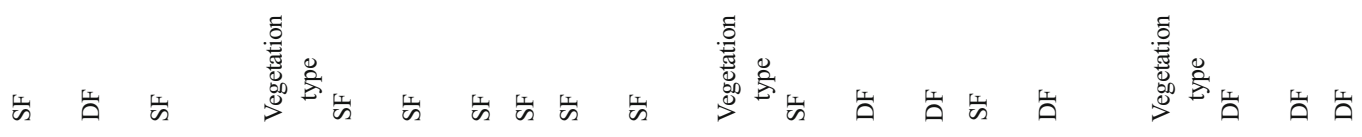

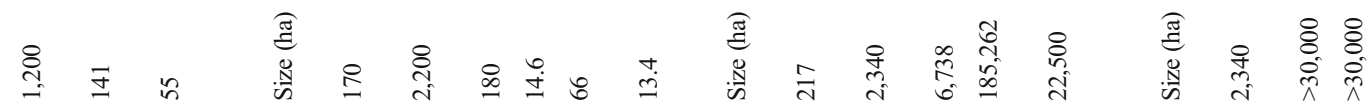

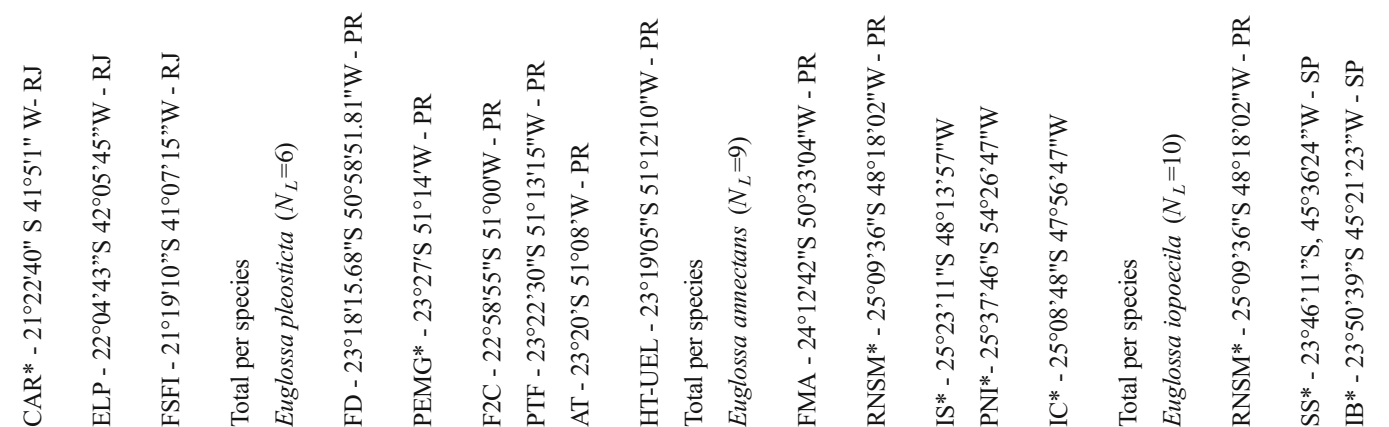




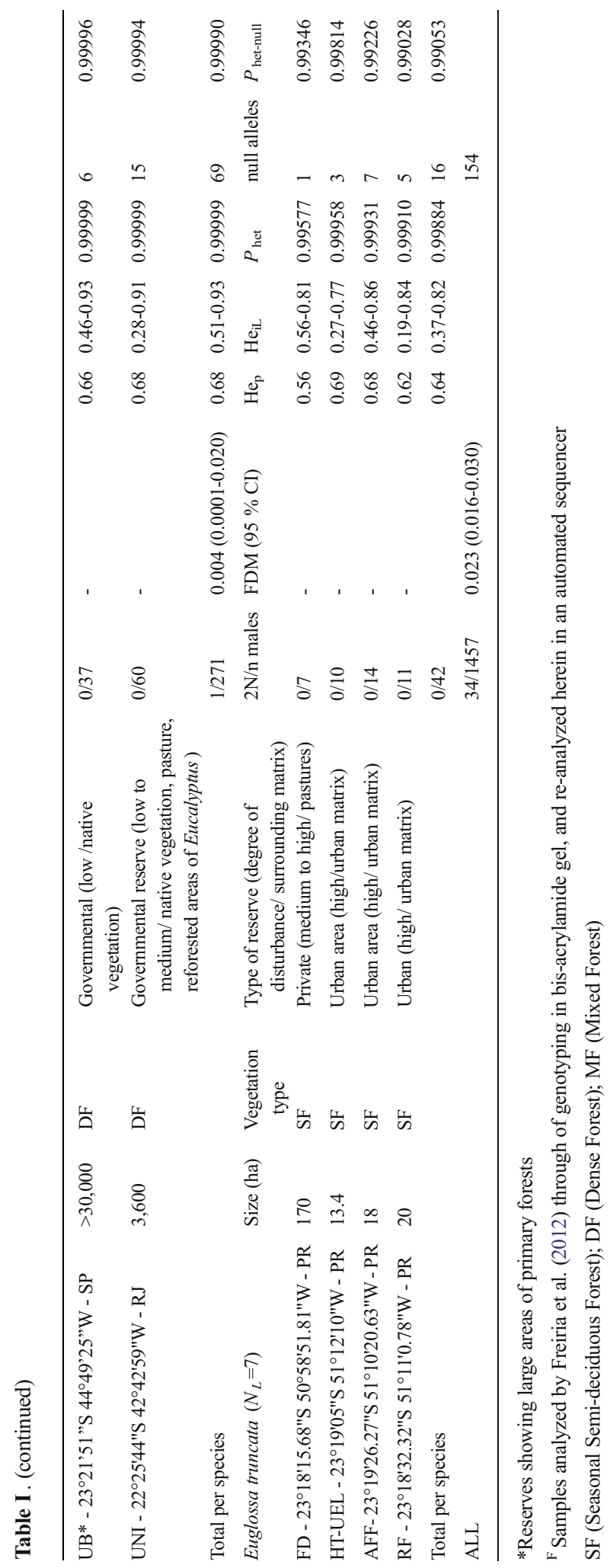


Males were collected in different forest fragments in the states of Rio de Janeiro, São Paulo, Paraná, Santa Catarina and Rio Grande do Sul (Table I, Figure 1). Other descriptions of the areas of the sampling sites are showed in Table I.

Individuals ( $\mathrm{n}=1457$; Table I) of these six species analysed here were sampled in different studies, with some variation in methodologies between these studies. In the case of males of El. cingulata, odour-baits were used with the following fragrances: methyl cinnamate, vanillin, eucalyptol, benzyl acetate and methyl salicylate. Samplings of this species occurred between May 2007 and May 2009, and the males were collected using aromatic traps (for details, see Aguiar and Gaglianone 2012). To sample the other euglossine species, aromatic traps and/or insect nets were used. To attract males of Ef. violacea, Eg. pleosticta and Eg. truncata, only three chemicals (eucalyptol, eugenol and vanillin) were used during the sampling, while in the case of $E g$. annectans and Euglossa iopoecila, in addition to these three fragrances, another five were used to attract males: beta-ionone, benzyl acetate, methyl salicylate, benzyl benzoate and methyl cinnamate. The period of sampling varied among these five species and from site to site: a) Males of Eufriesea violacea were collected in November and December of 2008 and 2009 (see Freiria et al. 2012); b) Eg. iopoecila: between 2009 and 2013; c) Eg. truncata in 2008; d) Eg. pleosticta from 2004 to 2009; and e) Euglossa annectans : between 2008 and 2013. Particularly in the case of this latter species, the samplings in the five study sites occurred as follows: FMA (Monte Alegre Farm) $=$ March/2008 - March/2010; RNSM (Salto Morato Reserve) $=$ April/2009 - October/2010; IS (Superagui Island)=November/2011-February/2013; PNI (Iguaçu Park)=March/2012; and IC (Cardoso Island $)=$ February $/ 2012$.

It is important to mention that the 353 males of Ef. violacea examined herein were those also studied by Freiria et al. (2012), but for the confirmation of diploid males, new analyses were performed on an automated sequencer, which confirmed only part of $2 \mathrm{~N}$ males previously identified by these authors.

In general the collecting effort per area was greater than 20 hours, distributed over several days of collecting and usually involving a minimum of five days of sampling. However, for Euglossa annectans, in the Ilha do Cardoso State Park (IC), Euglossa iopoecila, in São Sebastião (SS) and Ubatuba (UB), and, for Eufriesea violacea in NPR (Nazaré Paulista Reserve), CPCN-Pró Mata (CPCN Reserve) and Urussanga fragment (URU), sampling was carried out on only one or two days, resulting in a sampling effort less than 15 hours per area.

\subsection{DNA extraction and molecular analysis}

DNA extraction from Eufriesea violacea $(\mathrm{n}=353)$, Eg. annectans $(\mathrm{n}=203)$ and Eg. pleosticta $(\mathrm{n}=269)$ was performed as in Freiria et al. (2012), while DNA from males of Eulaema cingulata $(\mathrm{n}=319)$, Euglossa iopoecila $(\mathrm{n}=271)$ and Euglossa truncata $(\mathrm{n}=42)$ was obtained according to Almeida et al. (2001), with minor modifications, described as follows: parts of the body (legs or thorax) were placed in micro-centrifuge tubes containing $300 \mu \mathrm{L}$ extraction buffer ( $500 \mathrm{~mm}$ Tris-HCl, $20 \mathrm{~mm}$ EDTA, $10 \mathrm{~mm} \mathrm{NaCl}$, pH 8.0 and $1 \%$ SDS) and $5 \mu \mathrm{L} \mathrm{K}$ proteinase $(20 \mu \mathrm{g} / \mu \mathrm{L})$. Using small scissors, the body parts of bees were cut, held in a water bath at $63{ }^{\circ} \mathrm{C}$ for two hours and then subjected to phenolchloroform washes. The DNA obtained was resuspended in $30 \mu \mathrm{L}$ TE $(10 \mathrm{mM}$ Tris, $1 \mathrm{mM}$ EDTA, $\mathrm{pH}$ 8.0) and stored at $-20^{\circ} \mathrm{C}$. The concentration of DNA was measured using a DyNA Quant 200 fluorometer (Hoefer), following the quantification methodology proposed by the manufacturer. After reading, the DNA samples were diluted in water to a concentration of $5 \mathrm{ng} /$ $\mu \mathrm{L}$ to then be used in the amplifications.

The genetic analyses of euglossine males from the six species herein surveyed involved genotyping at a minimum of six (Ef. violacea and Eg. pleosticta) and a maximum of 10 microsatellite loci (Eg. iopoecila) (Table I), using primers developed for Eg. cordata (Souza et al. 2007), Eg. annectans (Paxton et al. 2009) and Eg. iopoecila (Penha et al. 2014). Amplifications of the different microsatellite loci of Ef. violacea, El. cingulata, Eg. pleosticta and Eg. annectans were based on protocols of Souza et al. (2007), Paxton et al. (2009) and Freiria et al. (2012), with some modifications. PCR reactions were produced in a final volume of $5 \mu \mathrm{L}$, including: $1 \mathrm{x}^{\text {GoTaq }^{\circledR}}{ }^{\circledR}$ Colorless Master Mix 2x (Promega), $0.5 \mu \mathrm{M}$ of tag-F primer $+0.5 \mu \mathrm{M}$ of R-primer mixture, $5 \mu \mathrm{M}$ M13-primer labelled with fluorochrome, $1 \%$ of glycerol, $5 \mathrm{ng}$ of DNA and $1.15 \mu \mathrm{L}$ nuclease-free water (Promega).

Samples were amplified in thermal cyclers (PCT-100 Peltier Thermal Cycler, MJ Research Inc. and Multigen LabNetBios), according to the protocol described 
below: $94{ }^{\circ} \mathrm{C}$ for 4 minutes followed by 35 cycles of: [ $94{ }^{\circ} \mathrm{C}$ denaturation for 40 seconds, 1 min for primer annealing at temperatures varying according to the primer and species, and extension at $72{ }^{\circ} \mathrm{C}$ for 1 minute], ending with an extension at $72{ }^{\circ} \mathrm{C}$ for 10 minutes. Furthermore, in the case of Eg. iopoecila and Eg. truncata, we employed a second amplification protocol: $94{ }^{\circ} \mathrm{C}$ for $4 \mathrm{~min}$, followed by 10 cycles de $94{ }^{\circ} \mathrm{C} /$ $30 \mathrm{~s}, 56{ }^{\circ} \mathrm{C} / 1 \mathrm{~min}, 72{ }^{\circ} \mathrm{C} / 1 \mathrm{~min}$, followed by 25 cycles $89{ }^{\circ} \mathrm{C} / 30 \mathrm{~s}, 56{ }^{\circ} \mathrm{C} / 1 \mathrm{~min}, 72{ }^{\circ} \mathrm{C} / 1 \mathrm{~min}$, with a final extension at $72{ }^{\circ} \mathrm{C}$ for 30 minutes. The primers and annealing temperatures employed in the amplification of microsatellite loci of the different species are shown in Table S1.

Sample genotyping was conducted in an automated sequencer (Applied Biosystems ${ }^{\circledR} 3500$ XL Genetic Analyzer) and GeneScan 600-LIZ (Applied Biosystems) was used as the standard marker. The sample genotypes were read using the GeneMarker 1.85 software (SoftGenetics) and checked visually. All samples that failed to amplify at any locus and all those indicating diploid males were re-amplified at least two more times. In our analyses we considered as diploid males only those cases for which heterozygous status of diploid males was confirmed in all three PCRs.

In all amplification reactions for analysis in the automated sequencer, the forward primers were modified at the 5' end with a tail (5'-TGTAAAACGACGGCCA GT-3'), according to the method proposed by Schuelke (2000), to which the M13 primer labelled with 6-FAM fluorophore (blue), NED (yellow) and HEX (green) was ligated. This methodology eliminates the need for individually labeling the forward primers of all loci (Schuelke 2000).

\subsection{Data analysis}

The expected heterozygosity (He) - intralocus and per population - were estimated with the software package TFPGA 1.3 (Miller 1997).

The calculation of $P_{\text {het }}$, i.e. a probability of the molecular marker to detect a diploid individual as heterozygous, was performed according to Souza et al. (2010). However, putative null alleles can cause difficulties in microsatellites scoring and can lead to an overestimation of $P_{\text {het }}$ (Souza et al. 2010; Boff et al. 2014). Like these authors, to account for putative null alleles we assumed that a male lacking an allele at a locus was caused by a null allele. Thus, we performed the calculation of $P_{\text {het-null }}$ applying the formula of Boff et al. (2014). In Table S2 we show the number of samples that failed to amplify for different loci surveyed for the different species and populations.

The binomial $95 \%$ confidence interval of the proportion of diploid males was calculated according to Souza et al. (2010) and Boff et al. (2014) (on-line tool at http://statpages.org/confint.html).

For species in which more than five study areas were analysed for the occurrence of $2 \mathrm{~N}$ males, the Pearson correlation index was used to test for a correlation between the size of the study areas and frequencies of diploid males. We used a Chi-square test to test for significant difference in the frequency of diploid males sampled in our study and by Souza et al. (2010); P values $<0.05$ were considered statistically significant.

\section{RESULTS}

From the total of 1457 males analysed, belonging to six different euglossine species, 34 were diploid, which were found only among four species distributed as follows: Ef. violacea $=7 ; \mathrm{El}$. cingulata $=3$; Eg. annectans $=23$ and Eg. iopoecila $=1$ (Table I).

Considering the frequency of diploid males in the total sample of each species, the highest frequency $(11.3 \%)$ was observed for Eg. annectans (Table I). Actually, diploid males were found in all five populations of this species surveyed in our study. Whereas the number of $2 \mathrm{~N}$ males of Eg. annectans varied only from three to seven, their frequencies varied across a larger range: from $6.7 \%$ (RNSM) to $27.3 \%$ (IC=Cardoso Island). Remarkably, among the five areas surveyed for this species, three showed frequencies of $2 \mathrm{~N}$ males above $10 \%$. However, for Eg.annectans as well the other euglossine species studied, our analyses showed no significant correlations $(P>0.05)$ between the size of the study area (forest fragment) and the number of $2 \mathrm{~N}$ males.

Finally, with regard to $P_{\text {het }}$ calculations, our analyses revealed that, even when null alleles were considered in our analyses $\left(P_{\text {het-null }}\right)$, the power of detecting diploid males was very high $(>0.99)$ for all species and populations surveyed (Table I), even for Eg. annectans . 


\section{DISCUSSION/ CONCLUSION}

Considering the variation in frequencies of diploid $(2 \mathrm{~N})$ males found for the six euglossine species surveyed in this study, our findings show that generalizations concerning the frequencies of such males among this group of bees should be avoided. This view is reinforced by both in the substantial number of males of each species from different populations analysed (except for $E g$. truncata ) and by the number of microsatellite loci used in the analyses, which varied from six to ten. Contrary to Souza et al. (2010), who found only five diploid males in a total sample of 1010 individuals belonging to 27 euglossine species, we detected 34 diploid males among the 1457 analysed. Considering that both studies employed the same microsatellite molecular markers and based their analyses mainly on the genotyping of samples in an automated sequencer, it is possible to see that a substantial difference was found between our results and those found by Souza et al. (2010). Indeed, through the Chi-square test, we found significant difference between the frequencies of $2 \mathrm{~N}$ males of these both studies $\left(\chi^{2}=12.96, d . f=1 ; P<0.0004\right)$. Except for $E g$. annectans, the frequencies of diploid males described in our study for the different species tended to be higher than those reported by Souza et al. (2010). Although it is difficult to explain such dissimilarities between both studies, the large number of individuals analysed per species in each study is a factor to be considered. In general, although Souza et al. (2010) analysed 1010 males, for many species these authors analysed only a few individuals. In fact, the number of bees surveyed by these authors varied from 1 (e.g. Eg. cognata, Eg. moure and Eg.viridis) to about 150 (e.g. El. bombiformes). From the 27 studied by Souza et al. (2010), 13 were represented by less than 20 individuals in the samples analysed. Also, for some species Souza et al. (2010) analysed only two or three microsatellite loci.

According to Owen and Packer (1994), in panmictic natural populations of bees the expected frequencies of $2 \mathrm{~N}$ males are low, $10 \%$ or less. In our study, populations of five of six euglossine species surveyed revealed frequencies of diploid males lower than $10 \%$ and, thus, they would be in accordance with the expected for panmictic populations. Conversely, three of the five populations of Eg. annectans showed estimates of $2 \mathrm{~N}$ males above $10 \%$. Regarding this species Souza et al. (2010) found a diploid male in a sample of 17 males analysed, i.e., at a frequency equal to $5.9 \%$. It should be emphasized here that our findings regarding the high frequency $(27.3 \%)$ of diploid males of Eg. annectans found to IC, an island population, must be viewed with caution, since only 11 individuals of this island were captured and analysed.

Although it has been shown that some euglossine bees are able to cross water bodies (Dressler 1982), a recent study showed that the sea seemed to act as a barrier to gene flow to $E g$. cordata populations (Boff et al. 2014). These authors detected that island isolation reduced genetic diversity in populations of this species, but did not significantly elevate diploid male production. Considering our data, it is worth noting that two of three Eg. annectans populations which showed frequencies of diploid males above $10 \%$ were island populations.

One of the causes for an increase of diploid males in populations of Euglossini and other groups of bees is the reduction in population size, with consequent loss of allelic diversity at the sex locus (Cook 1993; Roubik et al. 1996; Zayed et al. 2004; van Wilgenburg et al. 2006; Paxton et al. 2009). Thus, apparently, except for $E g$. annectans, the frequencies of diploid males detected for populations of euglossine species analysed in our study do not suggest any declines in populations of these species, since all of them showed frequencies of $2 \mathrm{~N}$ males within the range expected for panmictic populations (see Owen and Packer 1994). We should also consider that, in addition to null alleles, our estimates of diploid male may be elevated slightly because of overestimates of marker variability and unknown mating structure for majority of euglossine species herein studied.

All euglossine species surveyed in our study are endemic to the Atlantic Forest or show a strong association with this threatened South American forest (Faria Jr and Melo 2007; Nemésio and Silveira 2007; Nemésio 2009). 
With less than $10 \%$ of its original cover, the Atlantic Forest is today totally fragmented, with most of its remnants having sizes less than 100 ha and under significant human interference (Ribeiro et al. 2009). It is within this highly threatening scenario that populations of different euglossine species seek resources for their survival. Undoubtedly, those most sensitive species that depend more closely on more preserved forest areas are more susceptible to loss of genetic diversity. When considering the results especially related to Eg. annectans and its intimate distribution with the Atlantic Forest, this species merits the focus of further studies on population genetic structure, taking also into account variation in the frequencies of $2 \mathrm{~N}$ males.

Based on our findings, we suggest that, in addition to other euglossine species that have been pointed out as potentially more sensitive to habitat disturbance (Powell and Powell 1987; Tonhasca et al. 2002; Giangarelli et al. 2009), Eg. annectans is another Euglossini species sensitive to anthropogenic interference. However, since without a more complete knowledge about different factors which can affect diploid male production in bees, such as sex allele diversity, effective population size and dispersal rate, it is difficult to suggest whether the relatively higher frequencies of diploid males of Eg. annectans could be due to an increased incidence of inbreeding in the studied populations of this species. Based on that, we recommend further genetic studies involving a larger number of populations of this orchid bee species to corroborate or not the hypothesis that this orchid bee species is sensitive to habitat fragmentation.

Our results for Eg. annectans, which revealed the occurrence of diploid males in all remnants of Atlantic Forest where this species was sampled, suggest that we should pay more attention to populations of this species. Moreover, the results presented here indicate, regarding to frequency of diploid males in natural populations of orchid bees, that generalizations should be avoided since our findings highlighted that they are not invariably rare within this group of bees.

\section{ACKNOWLEDGMENTS}

The authors thank: Coordination of Improvement of Higher Education Personnel (CAPES)/Procad (158/ 2007), Brazilian Council for Scientific and Technological Development (CNPq), Fundação O Boticário de Proteção à Natureza (FBPN) and Klabin S.A. and Biota-FAPESP for financial support; IBAMA and IAP for environmental license; Instituto Florestal de São Paulo for the license for the collections and staff of State Parks of São Sebastião, Ilhabela, Ilha do Cardoso, Ubatuba (Picinguaba), for the infrastructure and help in field work; Isabel Alves-dos-Santos, Guaraci Duran Cordeiro and Samuel Boff by donation of the specimens of Euglossa iopoecila from Ilhabela; and owners of private reserves for permission for the collection of bees. D.C. Giangarelli thanks CAPES for the scholarship. Silvia H. Sofia and Maria C. Gaglianone are research fellows from the CNPq. The authors are also grateful to two anonymous referees for their valuable comments, which contributed to improve the quality of this paper.

Abeilles à orchidée : une nouvelle évaluation de la rareté de mâles diploïdes dans les populations de ce groupe de pollinisateurs néotropicaux

microsatellite / Euglossini / Euglossa annectans / fragments forestiers

Prachtbienen : Neue Daten zur Seltenheit diploider Männchen in Populationen dieser Gruppe neotropischer Bestäuber

Mikrosatelliten / Euglossini / Euglossine Bienen / Euglossa annectans / Waldfragmente

\section{REFERENCES}

Aguiar, W.M., Gaglianone, M.C. (2012) Euglossine bee communities in small forest fragments of the Atlantic Forest, Rio de Janeiro state, southeastern Brazil (Hymenoptera, Apidae). Rev. Bras. Entomol. 56, 210-219

Almeida, F.S., Fungaro, M.H.P., Sodré, L.M.K. (2001) RAPD and isoenzyme analysis of genetic variability in three allied species of catfish (Siluriformes, Pimelodidae) from the Tibagi river. Brazil. J. Zool. $253,113-120$

Beye, M., Hasselmann, M., Fondrk, M.K., Page, R.E., Omholt, S.W. (2003) The gene csd is the primary signal for the sexual development in the honeybee and encodes as SR-type protein. Cell 114, 419-429 
Boff, S., Soro, A., Paxton, R.J., Alves-dos-Santos, I. (2014) Island isolation reduces genetic diversity and connectivity but does not significantly elevate diploid male production in a neotropical orchid bee. Conserv. Genet. . doi:10.1007/s10592-014-0605-0

Cook, J.M. (1993) Sex determination in the Hymenoptera: a review of models and evidence. Heredity 71, 421435

Cook, J.M., Crozier, R.H. (1995) Sex determination and population biology of the Hymenoptera. Trends Ecol. Evol. 10, 281-286

Cowan, D.P., Stahlhut, J.K. (2004) Functionally reproductive diploid and haploid males in an inbreeding hymenopteran with complementary sex determination. Proc. Natl. Acad. Sci. USA 101, 10374-10379

Crozier, R.H. (1977) Evolutionary genetics of the Hymenoptera. Annu. Rev. Entomol. 22, 263-288

Dressler, R.L. (1982) Biology of orchid bees (Euglossini). Annu. Rev. Ecol. Syst. 13, 373-394

Elias, J., Mazzi, D., Dorn, S. (2009) No need to discriminate? Reproductive diploid males in a parasitoid with complementary sex determination. Plos One 4, e6024

Faria Jr., L.R.R., Melo, G.A.R. (2007) Species of Euglossa (Glossura) in the Brazilian Atlantic forest, with taxonomic notes on Euglossa stellfeldi Moure (Hymenoptera, Apidae, Euglossina). Rev. Bras. Entomol. 51, 275-284

Freiria, G.A., Ruim, J.B., Souza, R.F., Sofia, S.H. (2012) Population structure and genetic diversity of the orchid bee Eufriesea violacea (Hymenoptera, Apidae, Euglossini) from Atlantic Forest remnants in southern and southeastern Brazil. Apidologie 43, 392-402

Giangarelli, D.C., Freiria, G.A., Colatreli, O.P., Suzuki, K.M., Sofia, S.H. (2009) Eufriesea violacea (Blanchard) (Hymenoptera: Apidae): an orchid bee apparently sensitive to size reduction in forest patches. Neotrop. Entomol. 38, 1-6

Harpur, B.A., Sobhani, M., Zayed, A. (2013) A review of the consequences of complementary sex determination and diploid male production on mating failures in the Hymenoptera. Entomol. Exp. Appl. 146, 156-164

Heimpel, G.E., de Boer, J.G. (2008) Sex determination in the Hymenoptera. Annu. Rev. Entomol. 53, 209-230

López-Uribe, M.M., Almanza, M.T., Ordonez, M. (2007) Diploid male frequencies in Colombian population of euglossine bees. Biotropica 39, 660-662

Mattozo, V.C., Faria, L.R.R., Melo, G.A.R. (2011) Orchid bees (Hymenoptera: Apidae) in the coastal forests of southern Brazil: diversity, efficiency of sampling methods and comparison with other Atlantic forest surveys. Pap. Avulsos Zool. 51, 505-515

Milet-Pinheiro, P., Schlindwein, C. (2005) Do euglossine males (Apidae, Euglossini) leave tropical rainforest to collect fragrances in sugarcane monocultures? Rev. Bras. Zool. 22, 853-858
Miller, M.P. (1997) Tools for population genetic analyses (TFPGA) 1.3: A Windows program for the analysis of allozyme and molecular population genetic data. Computer software distributed by author

Nemésio, A. (2009) Orchid bees (Hymenoptera: Apidae) of Brazilian Atlantic Forest. Zootaxa 2041, 1-242

Nemésio, A. (2013) Are orchid bees at risk? First comparative survey suggests declining populations of forestdependent species. Braz. J. Biol. 73, 367-374

Nemésio, A., Silveira, F.A. (2007) Diversity and distribution of orchid bees (Hymenoptera: Apidae) with a revised checklist of their species. Neotrop. Entomol. 36, 874-888

Owen, R.E., Packer, L. (1994) Estimation of the proportion of diploid males in populations of Hymenoptera. Heredity $\mathbf{7 2}, 219-227$

Paxton, R.J., Zobel, M.U., Steiner, J., Zillikens, A. (2009) Microsatellite loci for Euglossa annectans (Hymenoptera: Apidae) and their variability in other orchid bees. Mol. Ecol. Resour. 9, 1221-1223

Penha, R.E.S., Gaglianone, M.C., Almeida, F.S., Boff, S.V., Sofia, S.H. (2014) Mitochondrial DNA of Euglossa iopoecila (Apidae, Euglossini) reveals two distinct lineages for this orchid bee species endemic to the Atlantic Forest. Apidologie . doi:10.1007/s13592-014-0329-7

Powell, A.H., Powell, G.V.N. (1987) Population dynamics of male euglossine bees in Amazonian forest fragments. Biotropica 19, 176-179

Ribeiro, M.C., Metzger, J.P., Martensen, A.C., Ponzoni, F.J., Hirota, M.M. (2009) The Brazilian Atlantic Forest: How much is left, and how is the remaining forest distributed? Implications for conservation. Biol. Conserv. 142, 1141-1153

Roubik, D.W., Hanson, P.H. (2004) Orchid bees of tropical America, $1^{\text {st }}$ edn. INBio, Santo Domingo de Heredia, Costa Rica

Roubik, D.W., Weight, L.A., Bonilla, M.A. (1996) Population genetics, diploid males, and limits to social evolution of euglossine bees. Evolution 50, 931-935

Schuelke, M. (2000) An economic method for the fluorescent labeling of PCR fragments. Nat. Biotechnol. 18, 233-234

Sofia, S.H., Suzuki, K.M. (2004) Comunidades de machos de abelhas Euglossina (Hymenoptera: Apidae) em fragmentos florestais no sul do Brasil. Neotrop. Entomol. 33, 693-702

Souza, R.O., Cervini, M., Del Lama, M.A., Paxton, R.J. (2007) Microsatellite loci for euglossine bees (Hymenoptera, Apidae). Mol. Ecol. Notes 7, 1352-1356

Souza, R.O., Del Lama, M.A., Cervini, M., Mortari, N., Eltz, T., Zimmermann, Y., Bach, C., Brosi, B.J., Suni, S., Quezada-Euán, J.J.G., Paxton, R.J. (2010) Conservation genetics of neotropical pollinators revisited: microsatellite analysis suggests that diploid males are rare in orchid bees. Evolution 64, 3318-3326

Takahashi, N.C., Peruquetti, R.C., Del Lama, M.A., de Oliveira, C.L.A. (2001) A reanalysis of diploid male frequencies in euglossine bees (Hymenoptera: Apidae). Evolution 55, 1897-1899 
Tonhasca, A., Blackmer, J.L., Albuquerque, G.S. (2002) Abundance and diversity of euglossine bees in the fragmented landscape of the Brazilian Atlantic Forest. Biotropica 34, 416-422

Unruh, T.R., Messing, R.H. (1993) Intraspecific biodiversity in Hymenoptera: implications for conservation and biological control. In: Gauld, I.D. (ed.) Lasalle, J, pp. 27-52. Hymenoptera and Biodiversity, CAB International, Wallingford

van Wilgenburg, E., Driessen, G., Beukeboom, L.W. (2006) Single locus complementary sex determination in Hymenoptera: an "unintelligent" design? Front. Zool. 3, 1-15

Zayed, A. (2009) Bee genetics and conservation. Apidologie 40, 237-262

Zayed, A., Packer, L. (2005) Complementary sex determination substantially increases extinction proneness of haplodiploid populations. Proc. Natl. Acad. Sci. USA 102, 10742-6

Zayed, A., Roubik, D.W., Packer, L. (2004) Use of diploid male frequency data as an indicator of pollinator decline. Proc. R. Soc. B 271, S9-S12 